\title{
Experimental studies of anomalous radon activity in the Tlamacas Mountain, Popocatepetl Volcano area, México: new tools to study lithosphere-atmosphere coupling for forecasting volcanic and seismic events
}

\author{
Anatoliy Kotsarenko ${ }^{1, \star}$, Vladimir Grimalsky ${ }^{2}$, Vsevolod Yutsis ${ }^{3}$, Ana Gabriela Bravo Osuna ${ }^{1}$, \\ Svetlana Koshevaya ${ }^{2}$, Hector Roman Peréz Enríquez ${ }^{1}$, G. Urquiza Beltrán ${ }^{2}$, \\ Jose Antonio Lopez Cruz Abeyro ${ }^{1}$, Carlos Valdés Gonzales ${ }^{4}$
}

\author{
${ }^{1}$ Universidad Nacional Autónoma de México (UNAM), Centro de Geociencias, Querétaro, Mexico \\ ${ }^{2}$ Universidad Autónoma del Estado de Morelos (UAEM), CIICAp, Cuernavaca, Morelos, Mexico \\ ${ }^{3}$ Universidad Autónoma de Nuevo León (UANL), Facultad de Ciencias de la Tierra, Nuevo León, Mexico \\ ${ }^{4}$ Universidad Nacional Autónoma de México (UNAM), Instituto de Geofísica, México D.F., Mexico
}

\section{Article history}

Received July 16, 2011; accepted December 12, 2011.

Subject classification:

Radon, Volcano eruption, Earthquake, Precursory phenomena, Atmosphere electricity, Lithosphere-atmosphere coupling.

\section{ABSTRACT}

This study presents and discusses the results of soil radon monitoring at three different volcano sites and one reference site, from December 2007 to January 2009. This relates to the activity of the Popocatepetl Volcano and a radon survey and gamma-ray spectrometry in the area between Paso de Cortes and Tlamacas Mountain, and in the adjacent regions. The results are applied to the aspects of atmosphere electricity and lithosphere-atmosphere coupling in relation to the forecasting of volcano and earthquake activity. The monitoring of radon release reveals a decrease in radon concentration (down to total suppression) with approaching moderate volcanic eruptions. The behavior of the radon activity at the Tlamacas site is more apparent, compared to other observational sites. The average level of radon release observed at the Tlamacas site is much higher, with some characteristic variations. Both the radon survey and gamma-ray spectrometry indicate intensive diffusion radon emission localized in the area of Tlamacas Mountain. The average radon concentration in the area of Tlamacas is about 10-20-fold greater than the background volcano values. The new concept of lithosphere-atmosphere coupling is presented: intensive radon release in high elevated areas shortens and modifies the Earth-to-thunderclouds electric circuit, which provokes microdischarges into the air close to the ground, attracting lightning discharges. This concept attempts to explain in a new way the noise-like geomagnetic emissions registered before major earthquakes, and it promotes interest for the study of thunderstorm activity in seismo-active zones, as a promising instrument for earthquake forecasting.

\section{Introduction}

The Popocatepetl Volcano (nicknamed «El Popo») is located in Central Mexico (latitude, $19.07^{\circ} \mathrm{N}$; longitude, $98.63^{\circ} \mathrm{W}$; altitude, $5,465 \mathrm{~m}$ ). It is one of the active volcanoes that forms the Trans-Volcanic Belt of Mexico (also know as the NeoVolcanic Axis), and its existence is related to the geodynamics of the North American and Coco plates. El Popo is a major potential hazard in Mexico, and therefore its eruptive activity is a subject of permanent monitoring by the National Center for Prevention of Disasters (CENAPRED). Every day, a summary of the behavior of Popocatepetl Volcano can be found on the CENAPRED webpage (http://www.cenapred.unam.mx/ cgi-bin/popo/reportes/ consultai.cgi).

The activity of Popocatepetl Volcano can be briefly summarized as follows. Light eruptions are permanent everyday events, with several to tens of eruptions of gas and water seen daily during the quiet volcano phases, and up to 50100 eruptions occurring in the active phases [see GonzálezPomposo 2004, and Table 2 in Arámbula-Mendoza et al. 2010, for detailed description of the recent Popocatepetl activity stages]. Moderate eruptions of gases and volcano ash take place from once every few months up to several times per day, for the quiet and active phases, respectively. Moderate eruptions can also be accompanied by explosive elements (rock ejection), with the frequency of such events as several to dozens of events per year in recent times. Major eruptive activity is not so frequent, and the last time it occurred it lasted from December 2000 to January 2001. At this stage, intensive rock expulsions, lava eruptions and pyroclastic flows can take place, in addition to the above-mentioned phenomena. Tectono-volcanic microseismic events with magnitudes up to Ms 2-3 and high frequency tremors are also part of the volcano activity. 
Our earlier studies in the Popocatepetl Volcano area (2003-2006) showed a variety of geomagnetic anomalies that were associated with volcano activity [Kotsarenko et al. 2007] and also allowed us to propose the hypothesis of the existence of a second magmatic reservoir [Kotsarenko et al. 2008]. The present study is devoted to various aspects of radon monotoring that was carried out in the first stage of our experimental investigations into the area of Popocatepetl Volcano (December 2007 to December 2009).

In the first part of this study, we present the results of the soil radon monitoring that was carried out at three different sites in the volcano area, and we discuss the phenomena that accompany volcano eruptions. Similar studies have been carried out in different active volcanoes all over the world, as a perspective tool for the forecasting of volcano hazard, including in Italy [Baurbon et al. 1991, Cigolini et al. 2001, 2005], France [Segovia et al. 1997, Toutain et al. 2002], Spain [Viñas et al. 2007], the Azores [Aumento 2002], Colombia [Londoño 2009], Costa Rica [Barquero et al. 2005, García-Vindas et al. 2002], Mexico [Armienta et al. 2002, Segovia 1991, Segovia et al. 1997, 1999, 2001, 2003, 2005, 2007, Varley and Armienta 2001, Varley 2003, Varley and Taran 2003], Nicaragua [Connor et al. 1996], and Indonesia [Baurbon et al. 1991].

The second part of this study deals with combined studies using radon surveys and gamma-ray spectrometry. Gamma rays are the most penetrating radiation from natural and man-made sources, so gamma-ray spectrometry is a powerful tool for monitoring and assessing the radiation environment [IAEA 1989, 2003]. Potassium, uranium and thorium are sensitive to tectonic fractionation, so that gamma-ray spectrometry provides a method of conveniently and rapidly measuring compositional changes over large areas of rough terrain [Thorpe 1995, Chiozzi et al. 1998]. Radon surveys are recognized as a reliable tool for revealing tectonic structures [King 1980, King et al. 1993, 1994, 1996, Chyi et al. 2002, Etiope et al. 2005, Vivek et al. 2005] and volcano-tectonic geological formations [Martín et al. 2003, Burton et al. 2004, Hernandez et al. 2004].

In the third part of the present study, we examine previously observed geomagnetic anomalies [Kotsarenko et al. 2007] and enhanced thunderstorm activity, in terms of the lithosphere-atmosphere coupling caused by intensive radon release under specific conditions in the area of Tlamacas Mountain.

\section{Soil radon monitoring in the Popocatepetl Volcano area}

\subsection{Equipment and methods}

Portable solid-state shallow subsurface radar (SHARAD) scout detectors were used for the monitoring of radon concentrations in the soil at the Tlamacas station site (latitude, $19.065^{\circ} \mathrm{N}$; longitude, $98.63^{\circ} \mathrm{W}$; referred to as «Tlamacas»), at a site near Paso de Cortes (latitude, $19.07^{\circ} \mathrm{N}$; longitude, $98.65^{\circ} \mathrm{W}$; «Paso de Cortes»), at a site near Tlamacas Mountain (latitude, $19.07^{\circ} \mathrm{N}$; longitude, $98.63^{\circ} \mathrm{W}$; «Tlamacas $\left.2 »\right)$, and at an Amecameca referent site (latitude, $19.12^{\circ} \mathrm{N}$; longitude, $98.77^{\circ} \mathrm{W}$ ) (Figure 1). These instruments use the diffusion
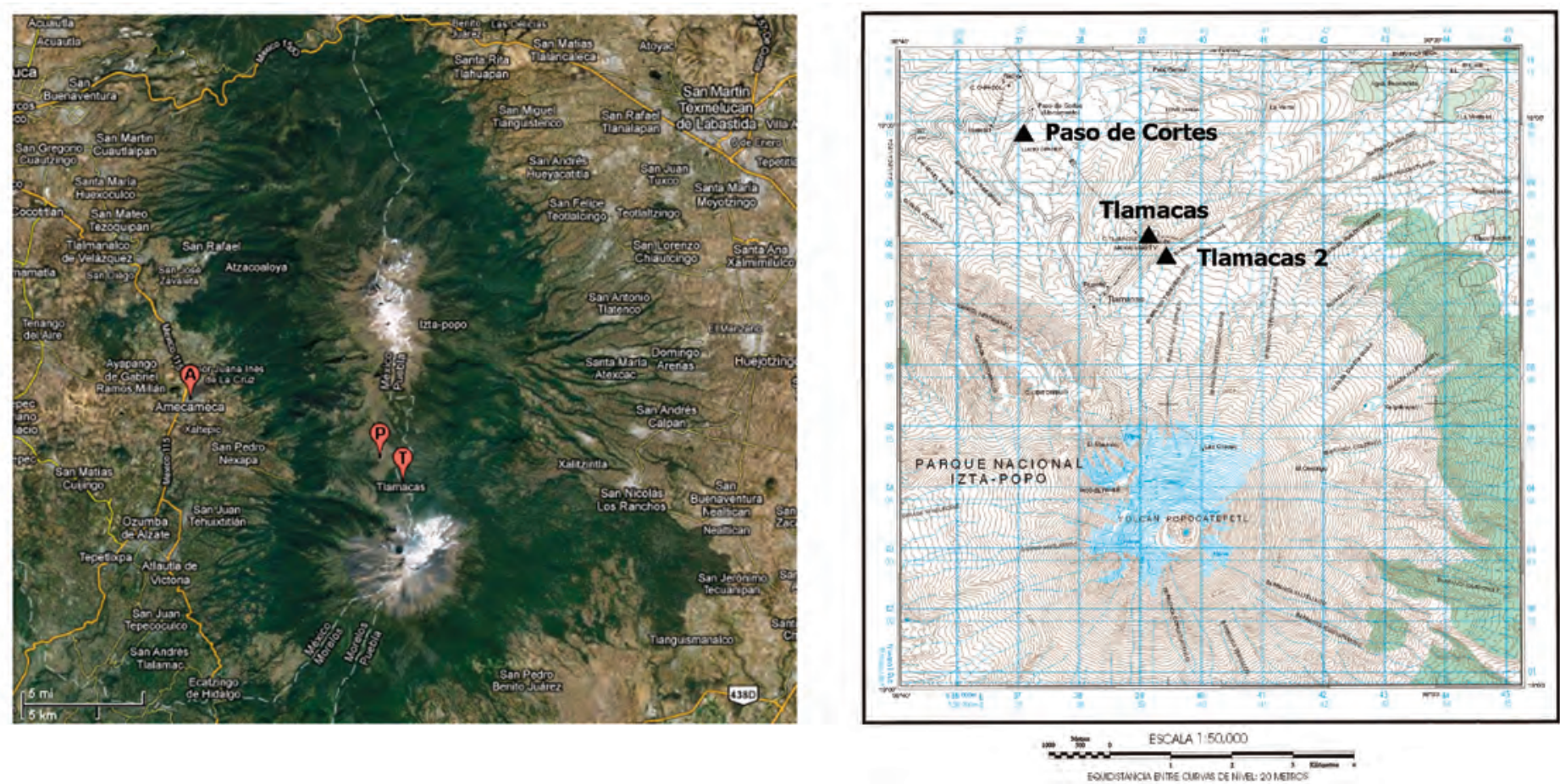

Figure 1. Left: Map showing the Amecameca referent site (A), and the Paso de Cortes (P) and Tlamacas (T) Sites. Right: Map of volcanic area showing the Paso de Cortes, Tlamacas and Tlamacas 2 sites. 


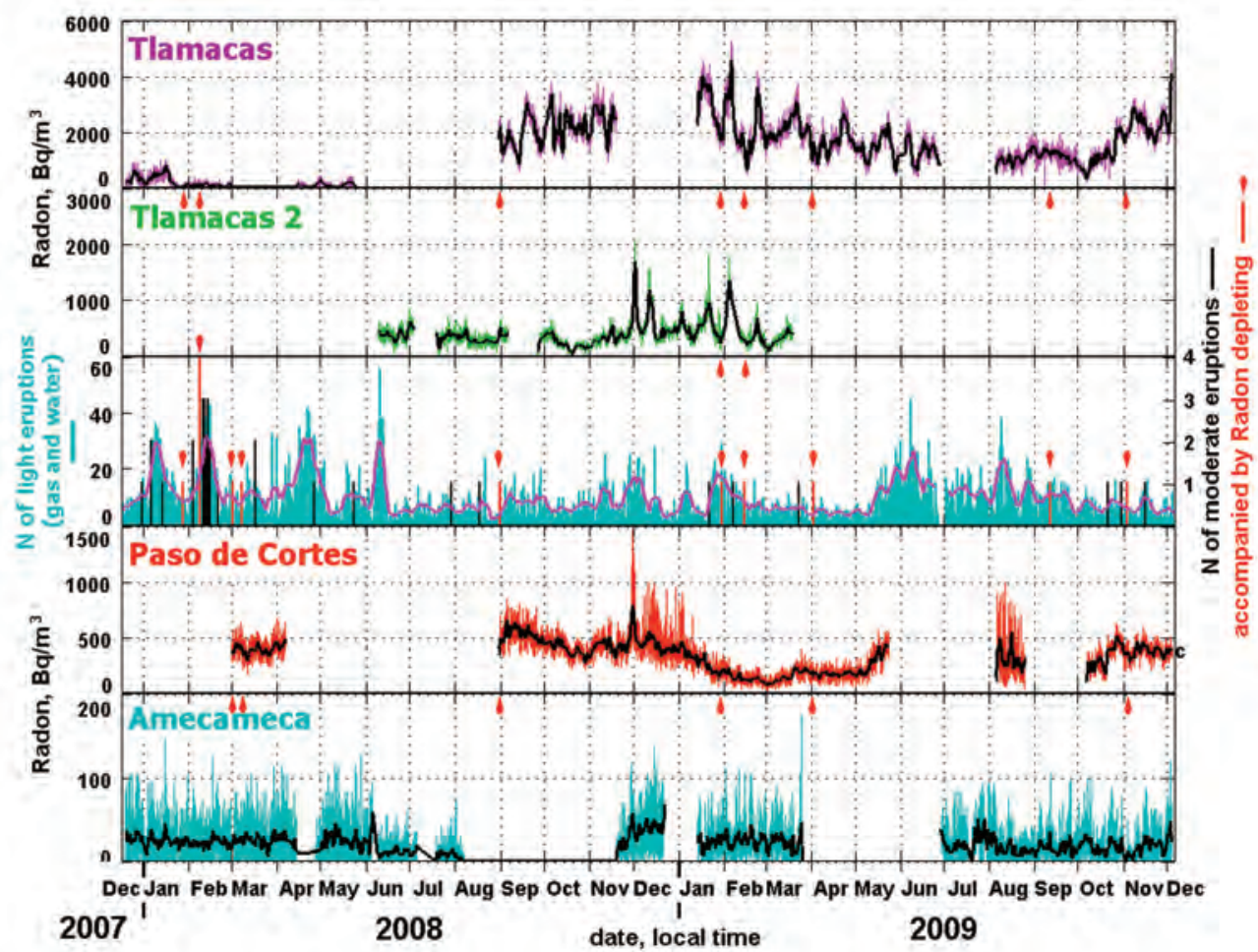

Figure 2. Radon emission monitoring at the three volcano sites. Top to bottom: Tlamacas, Tlamacas 2, Paso de Cortes and Amecameca referent site. Monitoring from December 2007 to December 2009. Middle panel: Volcano eruptions. Blue bars, eruptions of gas and water; black bars, moderate eruptions; red bars and arrows, moderate eruptions where radon decreases were observed.

method of air sampling (without pumping the air into the chamber), and therefore in a normal environment (here, «normal» meaning «not aggressive»; see Streil et al, 2008), the dominant monitored content comes from the most stable isotope of ${ }^{222} \mathrm{Rn}$ (referred to here as «radon»; $\mathrm{T}_{1 / 2}=3.8$ days; produced in the ${ }^{238} \mathrm{U}$ radioactive decay chain). Another isotope, ${ }^{220} \mathrm{Rn}$ (referred to here as «Toron»; $\mathrm{T}_{1 / 2}=55.6 \mathrm{~s}$; parent element, ${ }^{232} \mathrm{Th}$ ) is rarely detectable under normal environmental conditions, as it decays before it can penetrate into the chamber. The scout detectors were also equipped with simple sensors to measure the basic meteorological parameters: temperature, relative humidity, and atmospheric pressure, in addition to radon concentration. Nine detectors were used alternatively for measuring the radon at these monitoring sites, with sampling rates of 1 point per $60 \mathrm{~min}$ (for instruments with internal memory, $2047 \mathrm{pts}$ ), and 1 point per $90 \mathrm{~min}$ (1023 pts), to provide uninterrupted data for each consistent époque of measurements, with a duration of 1-2 months.

\subsection{Results and discussion}

The monitoring of the radon emissions at these four stations (Figure 2) showed some stable tendencies. First of all, the average values of the radon concentrations observed at the Tlamacas site were normally $1.5-5$-fold greater than those measured at the Tlamacas 2 site, 2-15-fold greater than at Paso de Cortes, and 25-400-fold greater than the Amecameca reference site values. Then, there was a distinct difference between the data recorded at the volcano sites. The Paso de Cortes and Tlamacas 2 data usually showed noise-like fluctuations around a stationary level, whereas the fluctuations at the Tlamacas station showed a kind of «alive» character, with radon levels that can change rapidly through the day.

In analyzing the radon concentration variations, we focused on the days with moderate eruptive activity, with the data of the eruptions obtained from the CENAPRED webpage. In the period analyzed, moderate eruptive activity was detected for a total of 27 days (39 eruptions, several with rock ejection, some days with 2-4 eruptions per day), 23 of which (32 eruptions) were covered by observations for at least at one volcano station. For 9 days (13 eruptions), we detected a clear decrease (depression) in the radon emmission before and during the eruptions (Figure 2, red bars and arrows). The radon release almost ceased for 4 days before the strongest event, that of January 28, 2008 (see Figure 3). During the day of this strongest event, intensive eruptive activity with rock and sporadic lava ejection were detected. Indeed, the period from January 28, 2008, to February 21, 2008, was when the most active eruptive activity was detected. At the same time, before the eruption on January 28,2008 , during the period of January $17-22,2008$, the radon concentrations fell from $900 \mathrm{~Bq} / \mathrm{m}^{3}$ to $200 \mathrm{~Bq} / \mathrm{m}^{3}$. Furthermore, another total radon decrease (which lasted about $20 \mathrm{~h}$ ) was detected before an eruption on February 11, 2008. For the following 19 days, which showed moderate eruptive activity, we detected 7 periods of radon decrease, 4 of 


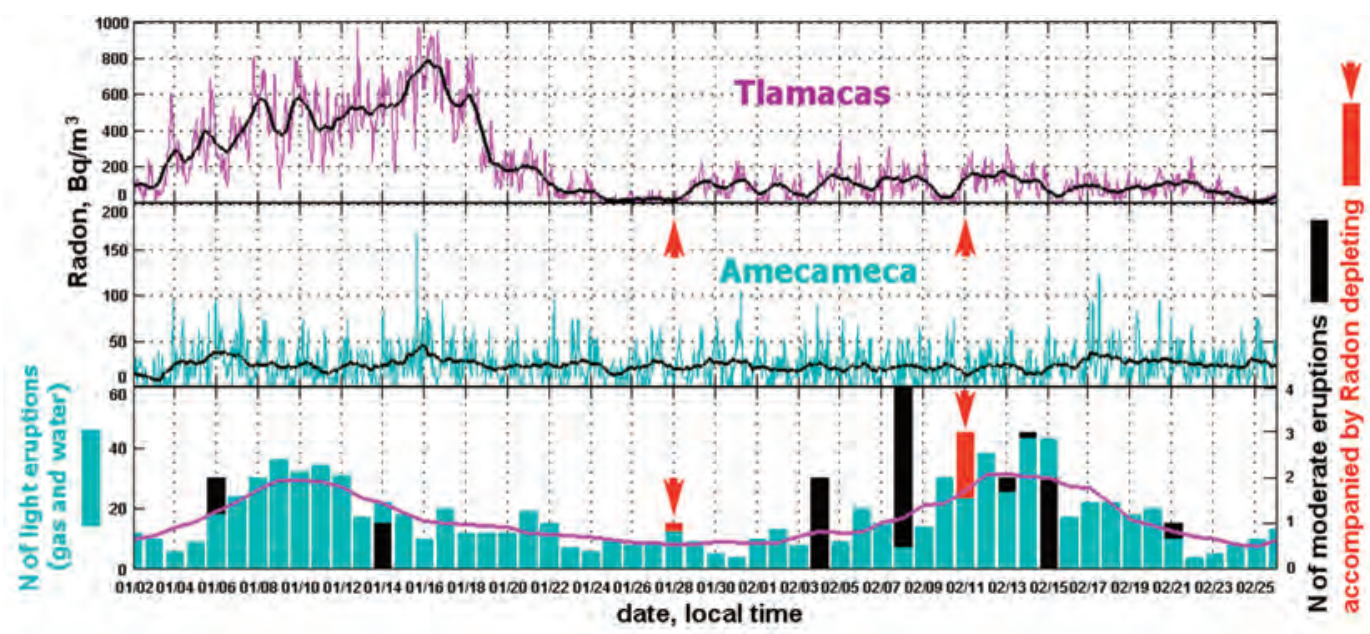

Figure 3. Radon emission monitoring. Top: Tlamacas volcano site. Middle: Amecameca referent site. Monitoring from January to February 2008. Bottom panel: Volcano eruptions. Blue bars, eruptions of gas and water; black bars, moderate eruptions; red bars and arrows, moderate eruptions where radon decreases were observed.

which were seen simultaneously for 2 or 3 of the volcano stations (in all other cases, the data were lost in 1 or 2 stations due to instrumental failure). Again, the most pronounced radon depletion was detected at the Tlamacas observation site, although the radon levels never decreased to zero. In many cases, moderate eruptions were not accompanied by decreases in the radon levels, and no eruptions occurred during some of the other radon decreases. Furthermore, there were better correlations between the radon changes observed at the Paso de Cortes and Tlamacas 2 sites than between these two sites and Tlamacas; the variations in the radon concentrations at the Tlamacas site were sometimes of a very peculiar character.

Summarizing this part of our studies, a couple of phenomena are worth considering. First of all, the radon behavior can be anticipated during moderate eruptions. Unlike the well-known intensifications of radon release before earthquakes, volcano systems are more ambiguous: many studies have reported increased radon emission before major events like explosions and pyroclastic flow, while others have also reported numerous decreases during moderate eruptive activity. Being a heavy gas, radon requires a transport mechanism from the depth where it is generated. This transport is provided by another volcano gas, carbon dioxide $\left(\mathrm{CO}_{2}\right)$. Streil et al. [2008] explained the depletion of radon as a shortage of $\mathrm{CO}_{2}$ due to geodynamic processes in the volcano system. Other, relatively unexpected results were the considerable difference in the radon de-gassing levels, and the periodic absence of correlation between Tlamacas and the other observation sites. Radon emissions depend on a variety of different factors, such as deposits of radioactive elements, presence of active tectonic structures, increased fracturing, soil porosity and penetrability, and meteorological conditions (most importantly, atmospheric pressure). The meteorological conditions at the volcanic observation sites were the same for all of the instruments, although no information was available about the radioactive deposits in these areas. For the soil composition and penetrability, the Tlamacas site is situated on a solid rock basement, while the Tlamacas 2 and Paso de Cortes sites lie on mellow soil. Thus, the natural activity of radon at these sites was expected to be higher, contrary to the results, as if Tlamacas Mountain was not an active geological structure.

\section{Radon survey and gamma-ray spectrometry in the Tlamacas area}

A combined study using a radon survey and gamma-ray spectrometry was performed for Tlamacas Mountain and in the nearby areas, to check our hypothesis relating to the anomalous character of the geodynamical processes of Tlamacas Mountain. Gamma-ray spectrometry was chosen as a credible tool to reveal possible radioactive deposits in the area, and to make a decision as to whether the radon emissions were of superficial (i.e. from uranium and thorium deposits) or subterranean (diffusion) origin.

\subsection{Equipment and methods}

We examined the area by measuring the variations in the total radiometric response, and $\mathrm{K}, \mathrm{U}$ and $\mathrm{Th}$ concentrations using a portable GRS 500 gamma-ray scintillometer spectrometer (Scintrex Ltd.). Each sample site had a series of 12 readings, with a duration of $10 \mathrm{~s}$ per reading $(0.1 \mathrm{cps})$, so the total time of observation for every site was $2 \mathrm{~min}$. This technique provides a rational minimization of the signal attenuation and a good signal-to-noise ratio.

The radon survey was carried out using the abovementioned radon scout instruments. As has been shown, radon emissions in volcano areas can change drastically, even over a single day. To avoid this problem, we limited the duration of our survey to daylight hours on one day, and used 
5 identical detectors to carry out simultaneous independent measurements. The test experiment was performed at the Tlamacas site to compare the instrument responses and determine the time domains (sampling) for any independent measurements. We placed the 5 instruments in a hole of about $1 \mathrm{~m}^{2}$, at $80 \mathrm{~cm}$ in depth, near the Tlamacas station, for 2 days of correlated measurements, with a $30 \mathrm{~min}$ sampling rate. The comparison of the characteristics obtained for the 5 detectors showed the need for correction of one detector (\#091), whereas the measurements of the other 4 detectors were comparable and within the instrumental error (Figure 4). The correction coefficient for detector \#091 was calculated as

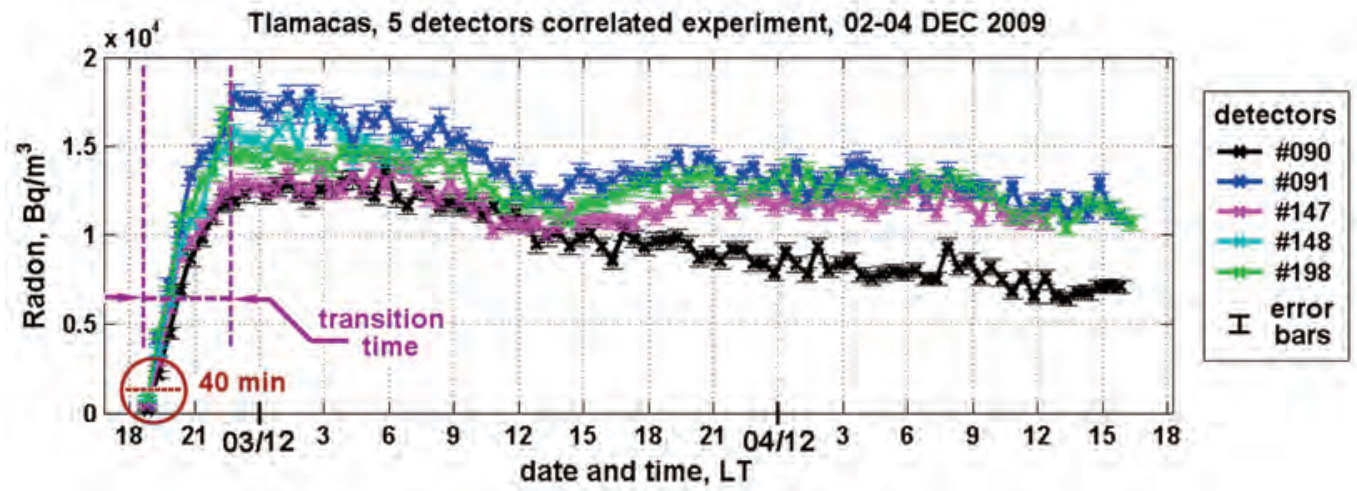

Figure 4. Correlated radon emission measurements for the five detectors tested. Tlamacas station site, December 2-4, 2009 (30 min sampling time).

\begin{tabular}{|c|c|c|c|c|c|c|}
\hline Reading Point & $\begin{array}{l}\text { Easting } \\
(\mathrm{km})\end{array}$ & $\begin{array}{l}\text { Northing } \\
(\mathrm{km})\end{array}$ & $\begin{array}{l}\text { Gamma ray total energy } \\
\qquad(\mathrm{cps})\end{array}$ & $\begin{array}{c}\text { Potassium } \\
(\%)\end{array}$ & $\begin{array}{l}\text { Equivalent uranium } \\
\text { (ppm) }\end{array}$ & $\begin{array}{l}\text { Equivalent thorium } \\
\text { (ppm) }\end{array}$ \\
\hline (TL1) TL-BL & 537.146 & 2110.417 & 159.712 & 0.250 & 2.066 & 6.713 \\
\hline TL2 & 539.091 & 2108.297 & 151.332 & 0.130 & 2.163 & 7.672 \\
\hline TL3 & 539.012 & 2108.286 & 196.544 & 0.054 & 3.933 & 8.333 \\
\hline TL4 & 539.169 & 2108.339 & 164.148 & 0.292 & 3.844 & 5.926 \\
\hline TL5 & 539.135 & 2108.181 & 212.951 & 0.095 & 5.200 & 7.407 \\
\hline TL6 & 538.960 & 2107.984 & 163.106 & 0.021 & 1.097 & 5.370 \\
\hline TL7 & 538.826 & 2107.817 & 157.049 & 0.123 & 0.954 & 6.173 \\
\hline TL8 & 538.663 & 2107.642 & 147.066 & 0.109 & 0.169 & 7.593 \\
\hline TL9 & 538.404 & 2107.462 & 167.172 & 0.024 & 6.124 & 8.519 \\
\hline TL10 & 538.171 & 2107.477 & 167.001 & 0.148 & 2.968 & 4.815 \\
\hline TL11 & 538.025 & 2107.383 & 180.070 & 0.027 & 2.488 & 6.019 \\
\hline TL12 & 537.874 & 2107.578 & 171.968 & 0.180 & 3.237 & 10.494 \\
\hline TL13 & 537.861 & 2107.794 & 143.492 & 0.817 & 0.680 & 0.200 \\
\hline TL14 & 537.733 & 2108.009 & 153.104 & 0.216 & 2.786 & 7.222 \\
\hline TL15 & 537.613 & 2108.297 & 157.569 & 0.125 & 1.884 & 7.819 \\
\hline TL16 & 537.873 & 2108.684 & 143.575 & 0.135 & 1.417 & 10.741 \\
\hline TL17 & 537.434 & 2108.569 & 166.170 & 0.438 & 0.889 & 5.787 \\
\hline TL18 & 537.283 & 2108.820 & 164.408 & 0.161 & 0.453 & 7.222 \\
\hline TL19 & 537.114 & 2109.041 & 165.309 & 0.460 & 7.026 & 7.778 \\
\hline TL20 & 536.870 & 2109.254 & 162.966 & 0.675 & 4.631 & 8.148 \\
\hline TL21 & 536.775 & 2109.404 & 162.445 & 0.398 & 2.040 & 7.037 \\
\hline TL22 & 536.794 & 2109.631 & 166.571 & 0.273 & 0.983 & 3.241 \\
\hline TL23 & 536.913 & 2109.870 & 161.624 & 0.121 & 0.165 & 7.639 \\
\hline TL24 & 536.988 & 2110.034 & 157.249 & 0.191 & 0.675 & 7.222 \\
\hline TL25 & 537.112 & 2110.222 & 166.682 & 0.442 & 0.822 & 4.861 \\
\hline TL26 & 536.561 & 2110.102 & 152.483 & 0.164 & 1.200 & 2.778 \\
\hline
\end{tabular}

Table 1. Gamma-ray analysis results (total counts above $0.08 \mathrm{MeV}$ ).

TL-BL, Local base station: Paso de Cortes. Easting, Northing, DATUM WGS84, UTM Zone 14. 


\begin{tabular}{|c|c|c|c|c|c|}
\hline $\begin{array}{l}\text { Point } \\
\mathrm{N}^{\circ}\end{array}$ & $\begin{array}{l}\text { Sensor } \\
\mathrm{N}^{\circ}\end{array}$ & $\begin{array}{l}\text { Latitude } \\
\left({ }^{\circ} \mathrm{N}\right)\end{array}$ & $\begin{array}{l}\text { Longitude } \\
\left({ }^{\circ} \mathrm{W}\right)\end{array}$ & $\begin{array}{l}\text { Radon } \\
\left(\mathrm{Bq} / \mathrm{m}^{3}\right)\end{array}$ & $\begin{array}{c}\text { Instrument } \\
\text { error (\%) }\end{array}$ \\
\hline 1 & all (1st test) & 19.0856 & 98.6536 & 6 & 98 \\
\hline 2 & 091 & 19.0832 & 98.6483 & 109 & 38 \\
\hline 3 & 148 & 19.0808 & 98.6494 & 235 & 24 \\
\hline 4 & 198 & 19.0676 & 98.6506 & 106 & 35 \\
\hline 5 & 090 & 19.0761 & 98.6497 & 31 & 71 \\
\hline 6 & 147 & 19.0742 & 98.6478 & 67 & 45 \\
\hline 7 & 091 & 19.0725 & 98.6461 & 156 & 33 \\
\hline 8 & 148 & 19.0703 & 98.6444 & 332 & 20 \\
\hline 9 & 198 & 19.0706 & 98.6414 & 119 & 33 \\
\hline 10 & 090 & 19.0697 & 98.6404 & 141 & 33 \\
\hline 11 & 147 & 19.0675 & 98.6422 & 17 & 100 \\
\hline 12 & 091 & 19.0650 & 98.6414 & 109 & 38 \\
\hline 13 & 148 & 19.0618 & 98.6401 & 125 & 33 \\
\hline 14 & 198 & 19.0592 & 98.6389 & 93 & 38 \\
\hline 15 & 090 & 19.0597 & 98.6368 & 78 & 45 \\
\hline 16 & 147 & 19.0594 & 98.6356 & 26 & 71 \\
\hline 17 & 091 & 19.0606 & 98.6332 & 529 & 17 \\
\hline 18 & 148 & 19.0628 & 98.6311 & 222 & 25 \\
\hline 19 & 198 & 19.0650 & 98.6292 & 119 & 33 \\
\hline 20 & 090 & 19.0664 & 98.6278 & 703 & 15 \\
\hline 21 & 147 & 19.0675 & 98.6267 & 1058 & 11 \\
\hline 22 & 091 & 19.0679 & 98.6281 & 1244 & 11 \\
\hline 23 & 148 & 19.0675 & 98.6275 & 2407 & 8 \\
\hline 24 & 198 & 19.0675 & 98.6286 & 904 & 12 \\
\hline 25 & 147 & 19.0669 & 98.6281 & 1757 & 9 \\
\hline 26 & all & 19.0671 & 98.6282 & 546 & 9 \\
\hline 27 & all & 19.0675 & 98.6278 & 2789 & 8 \\
\hline
\end{tabular}

Table 2. Radon concentration results (40 min sampling time).

1.37. An optimal sampling time of $40 \mathrm{~min}$ was used, to cover the selected area of our survey from Paso de Cortes to Tlamacas, with a spatial resolution of $200 \mathrm{~m}$ to $400 \mathrm{~m}$ found between independent points during the daylight hours of a single day.

\subsection{Results and discussion}

The results obtained are presented in Tables 1 and 2 , and shown in Figure 5. Above all, the gamma-ray spectroscopy revealed a moderately enhanced gamma -ray background (Figure 5a) at the top of Tlamacas Mountain, while the levels of uranium and thorium concentrations (Figure $5 c, d$ ) were found to be comparable with the average levels (Table 1). The radon survey confirmed the existence of a strong radon anomaly in the area of Tlamacas Mountain (Figure 5f): the radon released at the sites of Tlamacas Mountain was 10-20fold greater than the background level (Table 2). The lack of coincidence between the maximum of $\mathrm{Rn}$ and $\mathrm{U}$ or Th, respectively, indicated the subterranean (diffusion) origin of the radon. The location of the other three maxima of radon concentrations coincided well with three $\mathrm{Th} / \mathrm{U}$ ratio maxima. This might indicate a proportionality between the ${ }^{220} \mathrm{Rn}$ and ${ }^{222} \mathrm{Rn}$ isotopes in the total radon content, and that their origin most likely lies in superficial deposits of these mentioned elements. Thus, we have demonstrated our assumption relating to the active geological structure in the Tlamacas Mountain area. These results can explain the differences in radon behavior between Tlamacas and the other observational sites, as mentioned in Section 2.
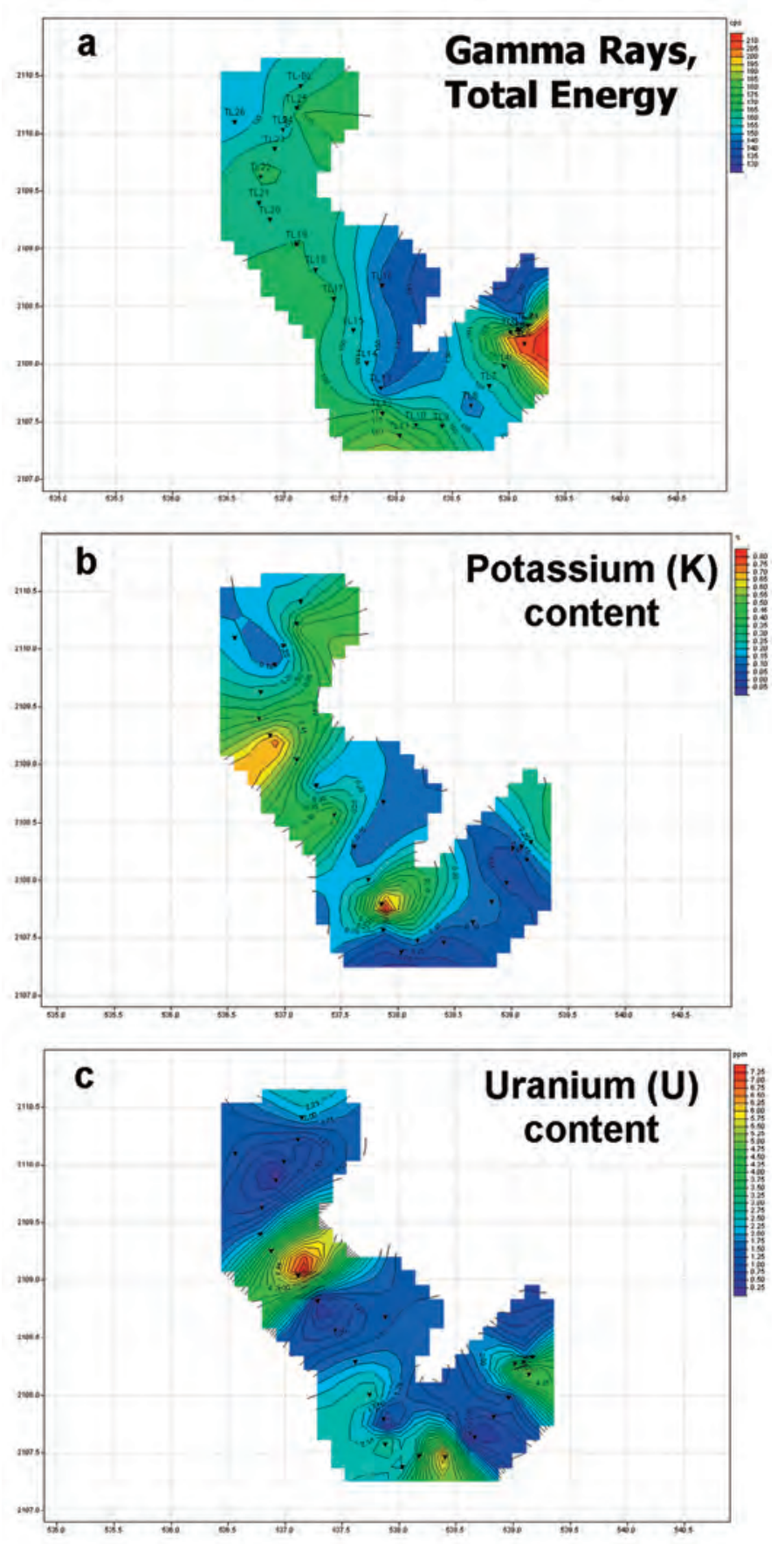

Figure 5a-c. (a) Gamma ray energy (total count above $0.08 \mathrm{MeV}$ ); (b) potassium (K; \%) content; (c) Uranium (U; ppm) content 

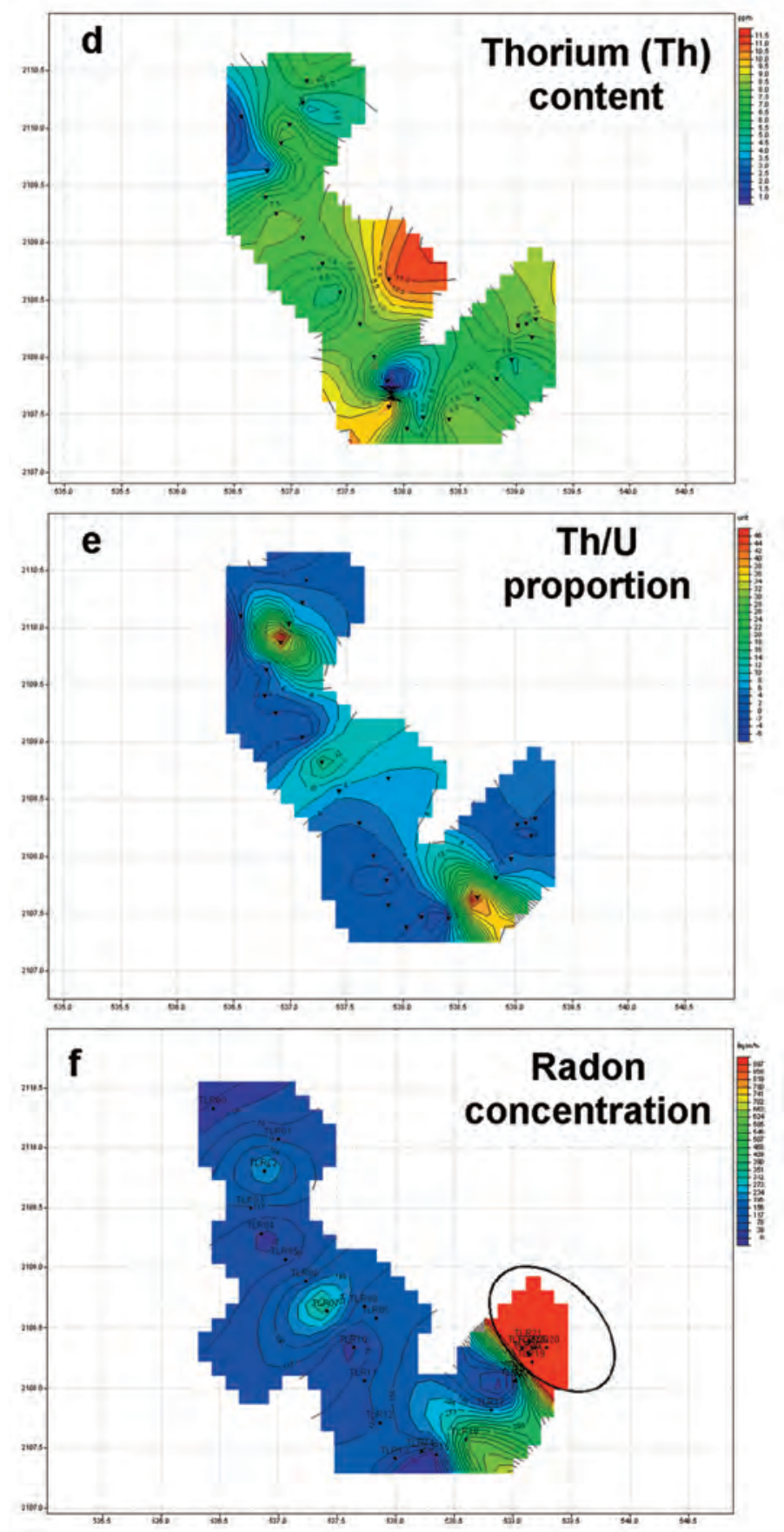

Figure 5d-f. (d) Thorium (Th; ppm) content; (e) Th/U ratio; and (f) Radon concentrations between the Tlamacas and Paso de Cortes stations (top part of the map) and in the area of Tlamacas Mountain (ellipse).

\subsection{Limitations of the radon survey method}

We should mention some clear limitation of our study. The SHARAD scout detectors were not equipped with pumps: the air sampling was carried out by natural diffusion. Due to this, the effective measurements of the actual values are obtained with some delay, which depends, first of all, on the volume of the pit and the correct radon concentration at the measurement site. Specifically, in our test experiment, the effective transition time was about $4 \mathrm{~h}$ (Figure 4). Under similar conditions, the values of radon measured in the first $40 \mathrm{~min}$
(Figure 4, red circle) will be 6-9-fold lower than the expected actual values. This means that our method is eligible in related units, i.e. it can serve to locate sites with anomalously increased radon values, but the absolute radon concentrations will be 69-fold greater than the detected values. In this regard, the radon map obtained (Figure 5f) is valid only for comparisons.

Another disadvantage of our method is that the daily values obtained can be affected by the diurnal variation. However, there is no effective way to avoid this drawback. In some cases, a base station can be established in the vicinity of the mapping area, to measure the diurnal variation, which can then be applied for the correction of the radon levels measured at different times. In our case, this method mentioned before is not reliable: all of the base stations should be established at least several days in advance of the survey, and remain at the site to obtain enough data for solid statistics. Furthermore, in «aggressive» environments such as volcanoes, diurnal variations can get lost among high levels of noise-like changes (which was also in our case).

\section{Radon and atmospheric electricity: new aspects of lithosphere-atmosphere coupling?}

\subsection{New view on the volcano and seismogenic geomagnetic} emissions

The intensive radon release for Tlamacas Mountain encouraged us to revise our earlier discovered phenomena [Kotsarenko et al. 2007, 2008]: long-term noise was observed in the geomagnetic field measured at the Tlamacas station (Figure 6). To estimate the noise contribution, we compared the noise character for the Tlamacas station registered during a highly perturbed day with a referent signal contaminated by electric welding measured $200 \mathrm{~m}$ away from the welding source in Campus Juriquilla, Querétaro, during the construction of a new building. The natural perturbations observed for Tlamacas were equal or even higher in amplitude compared with the intense corona discharge (electric welding currents of up to $100 \mathrm{~A}$ ).

How can this be connected to the observed radon emission phenomena? Increased radon release produces high ionization in the atmosphere [Pulinets and Boyarchuk 2004], which changes the electric field profile. Moreover, in the case of the Tlamacas station, an equivalent electric circuit between the Earth and thunderstorm clouds $(8-12 \mathrm{~km}$ ) changes strongly and gets much shorter for the altitude of Tlamacas Mountain $(4 \mathrm{~km})$. Thus, any heterogeneity in the ground surface becomes the source of micro-discharges, which are detected as integrated electromagnetic noise by the magnetometer.

\subsection{Thunderstorm lighting as a possible indicator of} forthcoming earthquakes

Another phenomenon of the same nature is often reported by witnesses: the frequency of lightning in the 

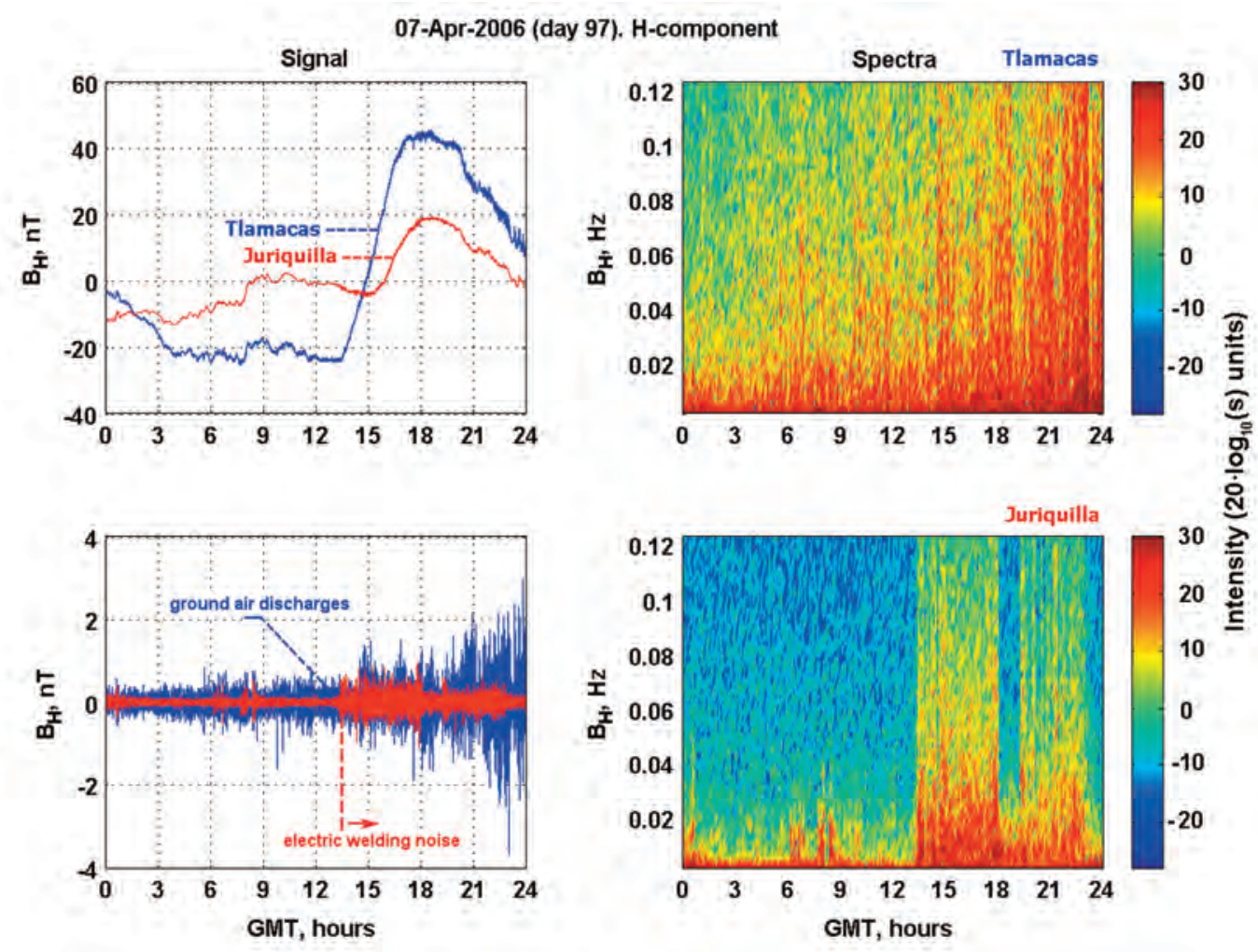

Figure 6. Geomagnetic signals. Left, top, Original signals; Left, bottom, Filtered signals. Blue, Tlamacas station; red, referent Juriquilla station. Right: Spectra measured at Tlamacas (top) and at the referent Juriquilla station (bottom, red).

Tlamacas Mountain is higher than in other sites (one such lightning strike destroyed our magnetometer and burned out a CPU despite the presence of a lightning-rod on the station building). This can also be explained in terms of the atmosphere electricity: the increased ionization and closeness to the thunderclouds attracts lightning, as happens during thunderstorms. These phenomena have significant scientific applications.

First of all, Tlamacas Mountain becomes a unique natural laboratory for experiments with atmosphere electricity. In terms of lithosphere-atmosphere coupling, Tlamacas Mountain performs as a natural reactor of ionization that modifies its electrical profile, provoking intensive integrated noise-like currents (by means of microdischarges) in the near-surface air layer, and enhanced thunderstorm activity between the Earth surface and the thunderstorm clouds.

Thus, the presented concept can re-interpret the noiselike geomagnetic emissions observed before major earthquakes in the earthquake preparation zone. The origin of these mentioned emissions might be attributed to the proposed mechanism of micro-discharges in the highly ionized superficial air.

Finally, we can propose the following hypothesis: monitoring of lighting activity in seismo-active areas can be of help for the forecasting of major earthquakes. The preliminary confirmation of this statement came from a study dedicated to the Alum Rock earthquake (October 30, 2007, California, USA) [Bleier et al. 2009]. This study examined the lightning activity in the earthquake preparation area, to remove the interference of thunderstorm-related pulses from geomagnetic signals. The maximum number of lightning strikes was detected the day before the earthquake in the area of the Sierra Nevada mountains. We believe that this is a similar example in nature to that presented in our study.

\section{Conclusions}

Our results of the radon monitoring at three different sites of Popocatepetl Volcano mountain and a referent site revealed that radon depletion preceded nine cases of moderate eruptive activity among 23 total events. The most pronounced reaction was observed at the Tlamacas observational site. The average radon concentration at the Paso de Cortes and Tlamacas two sites was significantly lower in comparison with that at Tlamacas; the radon variation in these other two sites has many specific features, while for the Tlamacas site, the radon behavior shows a more individual character.

The combined study using the radon survey and gamma-ray spectrometry revealed an anomalously increased diffusion radon emission localized in the area of Tlamacas.

A new concept is proposed regarding lithosphereatmosphere coupling in the case of Tlamacas, which appears 
to be similar in nature to a shortened electrical circuit from the Earth to the thunderstorm clouds (high-altitude mountains), such that the enhanced ionization caused by intensive radon release can explain, in a novel way, the noiselike geomagnetic emissions observed before destructive earthquakes. We also propose the study of thunderstorm activity in the earthquake preparation zone as a promising tool for the forecasting of destructive earthquakes.

Acknowledgements. We devote our article to the memory of our good friend Marcos Galicia Lopez, who always helped us in our volcano studies and who maintained the Tlamacas station. This work has been partially funded under the Mexican UNAM DGAPA PAPIIT projects IN120808 and IN109411.

\section{References}

Arámbula-Mendoza, R., C. Valdés-González and A. Martínez-Bringas (2010). Temporal and spatial variation of the stress state of Popocatépetl Volcano, Mexico, J. Volcanol. Geoth. Res., 196, 156-168.

Armienta, M.A., N. Varley and E. Ramos (2002). Radon and hydrogeochemical monitoring at Popocatépetl volcano, Mexico, Geofís. Internac., 41, 271-276.

Aumento, F. (2002). Radon tides on an active volcanic island: Terceira, Azores, Geofís. Int., 41, 499-505.

Barquero, J., E. Fernandez, M. Monnin, J.L. Seidel and N. Segovia (2005). Water chemistry and soil radon survey at the Poas volcano (Costa Rica), Annals of Geophysics, 48 (1), 33-42.

Baurbon, J.-C., P. Allardz, J.-C. Sabroux, D. Tedesco and J-P. Toutaln (1991). Soil gas emanations as precursory indicators of volcanic eruptions, J. Geol.. Soc. London, 148, 571-576.

Bleier, T., C. Dunson, M. Maniscalco, N. Bryant, R. Bambery and F. Freund (2009). Investigation of ULF magnetic pulsations, air conductivity changes, and infra red signatures associated with the 30 October Alum Rock M5.4 earthquake, Nat. Hazard Earth Sys., 9, 585603.

Burton, M., M. Neri and D. Condarelli (2004). High spatial resolution radon measurements reveal hidden active faults on Mt. Etna, Geophys. Res. Lett., 31, L07618; doi:10.1029/2003GL019181.

Chiozzi, P., V. Pasquale and M.Verdoya (1998). Ground radiometric survey of $\mathrm{U}$, Th and $\mathrm{K}$ on the Lipari Island, Italy, J. Appl. Geophys., 38, 209-217.

Chyi, L.L., C.Y. Chou, F.T. Yang and C.H. Chen (2002). Automated radon monitoring of seismicity in a fault zone, Geofís. Int., 41, 507-511.

Cigolini, C., F. Salierno, G. Gervino, P. Bergese, C. Marino, M. Russo, P. Prati, V. Ariola, R. Bonetti and S. Begnini (2001). High-resolution radon monitoring and hydrodynamics at Mount Vesuvius, Geophys. Res. Lett., 28,
4035-4038.

Cigolini, C., G. Gervino, R. Bonetti, F. Conte, M. Laiolo and D. Coppola (2005). Tracking precursors and degassing by radon monitoring during major eruptions at Stromboli Volcano (Aeolian Islands, Italy), Geophys. Res. Lett., 32, L12308; doi: 10.1029/2005GL022606.

Connor, Ch., B. Hill, P. LaFemina, M. Navarro and M. Conway (1996). Soil 222Rn pulse during the initial phase of the June-August 1995 eruption of Cerro Negro, Nicaragua, J. Volcanol. Geoth. Res., 73, 119-127.

Etiope, G., M. Guerra and A. Raschi (2005). Carbon dioxide and radon geohazards over a gas-bearing fault in the Siena Graben (central Italy), Terr. Atmos. Ocean. Sci., 16, 885-896.

García-Vindas, J.R., E. Fernández, E. Duarte and E. Malavassi (2002). Radon concentration anomalies as possible precursors to pyroclastic flow events of Arenal volcano, Geofís. Int., 41, 475-481.

González-Pomposo, G.J. (2004). Análisis de la sismicidad asociada a la actividad del volcán Popocatépetl y determinación de su estructura por medio de tomografía sísmica, PhD Thesis, Instituto de Geofísica, National University of Mexico, Mexico.

Hernandez, P., N. Perez, J. Salazar, M. Reimer, K. Notsu and H. Wakita (2004). Radon and helium in soil gases at Canadas caldera, Tenerife, Canary Islands, Spain, J. Volcanol. Geoth. Res., 131, 59-76.

IAEA (International Atomic Energy Agency) (1989). Construction and Use of Calibration Facilities for Radiometric Field Equipment (IAEA, Vienna), Tech. Rep. Series No. 309.

IAEA (Intrenational Atomic Energy Agency) (2003). Guidelines for radioelement mapping using gamma ray spectrometry data, IAEA-TECDOC-1363., 179 .

King, C.Y. (1980). Episodic radon changes in subsurface soil gas along active faults and possible relation to earthquakes, J. Geophys. Res., 85, 3065-3078.

King, C.Y., W. Zhang and B.S. King (1993). Radon anomalies on three kind of faults in California, Pure Appl. Geophys., 141, 111-124.

King C.Y., W.Zhang and B.S. King (1994). Radon anomalies on three kinds of faults in California, Pure Appl. Geophys., 141, 111-124.

King, C.Y., B.S. King and W.C. Evans (1996). Spatial radon anomalies on active faults in California, Appl. Geochem., 11, 497-510.

Kotsarenko, A., V. Grimalsky, R. Pérez Enríquez, C. Valdez-González, S. Koshevaya, J.A. López Cruz-Abeyro and V. Yutsis (2007). Volcano Popocatepetl, Mexico: ULF geomagnetic anomalies observed at Tlamacas station during March-July, 2005, Nat. Hazard Earth Sys., 7, 103-107.

Kotsarenko, A., V. Grimalsky, R. Pérez Enríquez, V. Yutsis, 
S. Koshevaya, J.A. Lopez Cruz-Abeyro, C. Valdez-Gonzalez and R.A. Villegas Cerón (2008). Geomagnetic anomalies observed at volcano Popocatepetl, Mexico, Adv. Geosci., 14, 21-24.

Londoño, J.M.B. (2009). Radon and $\mathrm{CO}_{2}$ emissions in different geological environments as a tool for monitoring volcanic and seismic activity, B. Geol., 31 (2), 83-95.

Martín, M.C., A. Ahijado, J. De la Nuez, M.L. Quesada, G. Steinitz, U. Vulkan and A. Eff-Darwich (2003). Radon survey at La Palma Island (Canary Islands): first results, Vulcânica, I, 113-116.

Pulinets, S. A., K. A. Boyarchuk (2004). Ionospheric Precursors of Earthquakes, Springer, Berlin, Heidelberg, New York, 316 p.

Segovia, N. (1991). Radon and volcanic activity, Recent Adv. Nucl. Tracks Radiat. Meas., 19, 409-413.

Segovia, N., M. Mena, M. Monnin, P. Peña, J.L. Seidel and E. Tamez (1997). Radon-in-soil, variations related to volcanic activity, Radiat. Meas., 28, 745-750.

Segovia, N., M. Mena, P. Peña, E. Tamez, J.L. Seidel, M. Monnin and C. Valdes (1999). Soil radon time series: Surveys in seismic and volcanic areas, Radiat. Meas., 31, 307-312.

Segovia, N., C. Valdes, P. Peña, M. Mena and E. Tamez (2001). Soil radon response around an active volcano, Radiat. Meas., 34, 433-436.

Segovia, N., M.A. Armienta, C. Valdes, M. Mena, J.L. Seidel, M. Monnin, P. Peña, M. B. E. Lopez and A.V. Reyes (2003). Volcanic monitoring for radon and chemical species in the soil and in spring water samples, Radiat. Meas., 36, 379-383.

Segovia, N., P. Peña, C. Valdés, M.A. Armienta, B. Lopez, G. Cisniega and M. Mena (2005). Radon, water chemistry and pollution check by volatile organic compounds in springs around Popocatepetl Volcano, Mexico, Annals of Geophysics, 48 (1), 85-91.

Segovia, N., M.I. Gaso and M.A. Armienta (2007). Environmental radon studies in Mexico, Environ. Geochem. Health., 29, 143-153; doi: 10.1007/s10653-006-9069-6.

Streil, T., V. Oeser and M. Ogena (2008). Continuous measurement of geo-chemical parameters in aggressive environment, Uranium, Min. Hydrogeol., 903-906; doi: 10.1007/978-3-540-87746-2_117.

Thorpe, R.S., A.G. Tindle and O. Williams-Thorpe (1995). Radioelement distribution in the Tertiary Lundy granite (Bristol Channel, UK), Geol. Mag., 132, 413-425.

Toutain, J.P., J.C. Baubron and L. Francois (2002). Runoff control of soil degassing at an active volcano. The case of Piton de la Fournaise, Reunion Island, Earth Planet. Sci. Lett., 197, 83-94.

Varley, N.R. and M.A. Armienta (2001). The absence of diffuse degassing at Popocatépetl Volcano, Mexico, Chem. Geol., 177, 157-173.
Varley, N.R. (2003). Soil gas concentration at Popocatépetl, México, Vulcânica, I, 155-162.

Varley, N.R. and Y. Taran (2003). Degassing processes of Popocatepetl and Volcán de Colima, Mexico, In: edited by C. Oppenheimer, D.M. Pyle and J. Barclay, Volcanic Degassing, Geological Society, London, Special publications, 213, 263-280.

Viñas, R., A. Eff-Darwich, V. Soler, M.C. Martín-Luis, M.L. Quesada and J. De la Nuez (2007). Processing of radon time series in underground environments: Implications for volcanic surveillance in the island of Tenerife, Canary Islands, Spain, Radiat. Meas., 42, 101-115.

Vivek, W., T.C. Su, C.C. Fu and T.F. Yang (2005). Spatial variations of radon and helium concentrations in soil-gas across the Shan-Chiao fault, Northern Taiwan, Radiat. Meas., 40, 513-516.

\footnotetext{
${ }^{\star}$ Corresponding author: Anatoliy Kotsarenko Universidad Nacional Autónoma de México (UNAM), Centro de Geociencias, Querétaro, Mexico; e-mail: kotsarenko@geociencias.unam.mx

C 2012 by the Istituto Nazionale di Geofisica e Vulcanologia. All rights reserved.
} 